Raymond Kozody MD FRCP(C),

Bill Ong MD FRCP(C),

Richard J. Palahniuk MD FRCP(C),

John G. Wade MD FRCP(C),

Maureen O. Cumming RN B SC, Wayne R. Pucci

\title{
Subarachnoid bupivacaine decreases spinal cord blood flow in dogs
}

Eigtheen mongrel dogs were randomized into two equal groups. Cervical, thoracic and lumbosacral spinal cord and spinal dural blood flows were measured using the radioactive microsphere technique. Blood flow determinations were made prior $t o$, and 20 and 40 minutes following lumbar subarachnoid injection of: (1) 0.4 per cent bupivacaine $(20 \mathrm{mg})$, or (2) 0.4 per cent bupivacaine $(20 \mathrm{mg})$ with $1 / 25,000$ epinephrine $(200 \mu \mathrm{g})$.

In dogs given subarachnoid bupivacaine or bupivacaine with epinephrine, the maximum decrease in mean arterial blood pressure ( 33 per cent) occurred at 40 minutes post-injection. Cardiac index decreased in dogs given subarachnoid bupivacaine $\left(197 \pm 1 / \mathrm{ml} \cdot \mathrm{kg}^{-1} \cdot \mathrm{min}^{-1}\right.$ control vs. $141=19 \mathrm{ml} \cdot \mathrm{kg}^{-1} \cdot \mathrm{min}^{-1}$ at 40 minutes $)$, while it increased in dogs given bupivacaine with epinephrine (201 $\pm 11 \mathrm{ml} \cdot \mathrm{kg}^{-1} \cdot \mathrm{min}^{-1}$ - control vs. $252 \pm 15$ $\mathrm{ml} \cdot \mathrm{kg}^{-1} \cdot \mathrm{min}^{-1}$ at 40 minutes). Dogs receiving subarachnoid bupivacaine demonstrated a significant decrease in spinal cord blood flow to all regions. Dogs receiving subarachnoid bupivacaine with epinephrine demonstrated a significant decrease in thoracic and lumbosacral spinal cord blood flow; however, cervical

\section{Key words}

ANAESTHETIC TECHNIQUES: subarachnoid block; ANAESTHETICS, LOCAL: bupivaCaine; SYMPATHETIC NERVOUS SYSTEM, CATECHOLAMINES: epinephrine; SPINAL CORD: blood flow.

From the Department of Anaesthesia, University of Manitoba, Winnipeg, Manitoba.

Address correspondence 10: Dr. Raymond Kozody, Department of Anaesthesia, University of Manitoba, Health Sciences Centre, 700 William Avenue,

Winnipeg, Manitoba, Canada R3E 0Z3.

Supported by University of Manitoba Faculty Fund Grant \#363-3111-07. cord blood flow remained unchanged. Thoracic and lumbosacral dural blood flows were significantly decreased in both groups following subarachnoid injection.

Subarachnoid bupivacaine 0.4 per cent $(20 \mathrm{mg}$ ) and 0.4 per cent with epinephrine $1 / 25,000(200 \mu \mathrm{g}) \mathrm{de}$ crease spinal cord and spinal dural blood flow in dogs.

Bupivacaine is a local anaesthetic agent which is extensively used in spinal and epidural anaesthesia. The reasons for its popularity are related to consistent anaesthetic effect, high degree of protein binding, good neurological safety record and its long duration of action. However, in clinical situations, especially when using spinal anaesthesia, the duration of bupivacaine black may be inadequate. Attempts to prolong the duration of bupivacaine spinal anaesthesia through the use of adjunctive epinephrine initially appeared promising, but have subsequently been shown to be ineffective.$^{1-3}$ This is in contrast to tetracaine spinal anaesthesia which is prolonged with the addition of epinephrine. ${ }^{4,5}$ The mechanism of epinephrine augmented prolongation of tetracaine spinal anaesthesia appears to be related to prevention of spinal cord vasodilation. ${ }^{6}$

The indirect evidence suggests that bupivacaine may have a different effect than tetracaine on spinal cord blood flow. This concept is strengthened by pharmacokinetic data showing that blood levels of bupivacaine following subarachnoid injection are similar whether or not epinephrine is used. '

The study was therefore undertaken to determine the effects of subarachnoid bupivacaine $(20 \mathrm{mg})$ and bupivacaine $(20 \mathrm{mg})$ with epinephrine $(200 \mu \mathrm{g})$ on spinal cord blood flow in dogs.

\section{Methods}

Eighteen mongrel dogs of either sex weighing $16-28 \mathrm{~kg}$ (18 $\pm 4 \mathrm{~kg}$, mean \pm S.D.) were studied. 
Anaesthesia consisted of intravenous pentobarbitone $30 \mathrm{mg} \cdot \mathrm{kg}^{-1}$, followed by a maintenance dose of $2-5 \mathrm{mg} \cdot \mathrm{kg}^{-1} \cdot \mathrm{hr}^{-1}$. After tracheal intubation, dogs were ventilated using an Ohio Model 300 ventilator with 100 per cent $\mathrm{O}_{2}$ at a tidal volume of $10-15 \mathrm{ml} \cdot \mathrm{kg}^{-1}$. The respiratory rate $(8-15 / \mathrm{min})$ was adjusted to maintain a $\mathrm{PaCO}_{2}$ of $35-42 \mathrm{mmHg}$. Guidelines for the humane use of animals as set forth by the University of Manitoba were followed.

The surgical preparation consisted of a right inguinal incision for insertion of polyvinyl catheters in the femoral artery and vein. A left inguinal incision was used for the retrograde insertion of a catheter through the femoral artery into the left ventricle using continuous pressure monitoring. A Swan Ganz thermodilution catheter was inserted into the pulmonary arterial circulation using the left jugular vein.

Following the surgical preparation each animal was allowed to stabilize for 40 minutes. Mean arterial blood pressure (MABP) and mean pulmonary artery pressure (PAP) were measured continuously using Statham transducers calibrated to zero at the mid-thoracic level. Heart rate (HR) was measured continuously, while PCWP was determined prior to and between flow determinations. Data were recorded using a Hewlett-Packard monitor (Model 7758C) and recorder (Model 7758A). Cardiac output (CO) was determined in duplicate prior to flow determinations, by the thermodilution of $5 \mathrm{ml}$ of 0.9 per cent saline at room temperature using an Edwards cardiac output computer (Model $9520 \mathrm{~A})$. A variation of less than five per cent between measurements was accepted.

Core temperature was continuously measured using the thermistor on the thermodilution catheter. $\mathrm{PaCO}_{2}, \mathrm{PaO}_{2}$ and $\mathrm{pH}$ were measured at five to ten minute intervals and immediately preceding each flow determination. Blood was withdrawn from the femoral arterial catheter, analyzed on a Corning Blood Gas Machine, and temperature corrected.

All dogs were initially fluid loaded with 0.9 per cent saline solution at $38^{\circ} \mathrm{C}$ to a PCWP $>4 \mathrm{mmHg}$. Subsequent fluid administration was based on maintaining PCWP at pre-injection values.

Following the stabilization period, control spinal cord and dural arterial blood flow was measured by the radioactive microsphere technique. The methodology has been outlined in detail in previous publications. ${ }^{7,8}$ In short, a suspension of $6-10 \times$
$10^{6}$ microspheres (3M Company) $15 \pm 0.5$ microns in diameter labelled with Cerium ${ }^{141}$, Chromium ${ }^{51}$ or Strontium ${ }^{85}$, is thoroughly mixed in saline and injected over ten seconds into the left ventricle. Ten seconds prior to injection, withdrawal of blood from the femoral artery is started using a Harvard withdrawal pump (Model 940), and continued for 30 seconds after completion of the left ventricular injection. Radioisotope counts from blood and tissue samples were determined using a Searle Mark III scintillation counter. By comparing microsphere counts trapped in the tissue, to counts in the arterial blood supplying that tissue (arterial reference sample), we were able to calculate regional tissue blood flow. Three blood flow determinations to each tissue region were made using the three different radioactive microsphere labels.

Following control blood flow measurements, a lumbar dural puncture was performed at the $\mathrm{L}_{5}-\mathrm{L}_{6}$ or $\mathrm{L}_{6}-\mathrm{L}_{7}$ interspace using a 22 gauge spinal needle. Successful dural penetration was evidenced by the free flow of one to two drops of cerebral spinal fluid from the needle hub.

Animals were randomly assigned to receive one of two solutions intrathecally:

a. 0.4 per cent bupivacaine $(20 \mathrm{mg})$ in 0.9 per cent saline $-5 \mathrm{ml}$

b. 0.4 per cent bupivacaine $(20 \mathrm{mg}$ ) with $1 /$ 25,000 epinephrine $(200 \mu \mathrm{g})$ in 0.9 per cent saline $5 \mathrm{ml}$.

The solutions were prepared by diluting $4 \mathrm{ml}$ of 0.5 per cent preservative free bupivacaine with 0.9 per cent saline to a final volume of $5 \mathrm{ml}$. All solutions were injected at $37^{\circ} \mathrm{C}$ and the rate of injection was standardized at $0.5 \mathrm{ml} \cdot \mathrm{sec}^{-1}$. Following intrathecal injection, the needle was removed and the dogs were placed supine. Blood flow measurements were performed at 20 and 40 minutes after intrathecal injection.

Following the blood flow measurements, the arterial line was opened and the animals exsanguinated. The spinal cord and dura was removed intact and divided into cervical, thoracic, and lumbosacral regions. The dura was dissected from the spinal cord and microsphere counts were performed on each cord and dural specimen. Blood flow to the spinal cord and dural regions was calculated as described.

All data were analyzed using analysis of variance and Student's paired and unpaired t-tests where 
TABLE I Haemodynamic parameters prior to and following intrathecal injection

\begin{tabular}{lcclll}
\hline Groups & $\begin{array}{l}\text { MABP } \\
(\mathrm{mmHg})\end{array}$ & $\begin{array}{l}P A P \\
(\mathrm{mmHg})\end{array}$ & $\begin{array}{l}P C W P \\
(\mathrm{mmHg})\end{array}$ & $\begin{array}{l}C O \\
\left(\mathrm{ml} \cdot \mathrm{kg}^{-1} \cdot \mathrm{min}^{-1}\right)\end{array}$ & $\begin{array}{l}\text { H.R. } \\
(\text { beats/min) }\end{array}$ \\
\hline $\begin{array}{l}\text { Bupivacaine } \\
\text { Pre-injection }\end{array}$ & $123 \pm 6$ & $16 \pm 1$ & $7 \pm 1$ & $197 \pm 11$ & $182 \pm 6$ \\
20 min post-injection & $87 \pm 3^{*}$ & $14 \pm 1$ & $8 \pm 1$ & $147 \pm 16^{*}$ & $121 \pm 7^{*}$ \\
40 min post-injection & $83 \pm 3^{*}$ & $14 \pm 1$ & $8 \pm 1$ & $141 \pm 19^{*}$ & $123 \pm 7^{*}$ \\
& & & & & \\
Bupivacaine wth epinephrine & $110 \pm 4$ & $14 \pm 1$ & $7 \pm 1$ & $201 \pm 11$ & $171 \pm 9$ \\
Pre-injection & $74 \pm 3^{*}$ & $15 \pm 1$ & $7 \pm 1$ & $267 \pm 14^{*}$ & $143 \pm 8$ \\
20 min post-injection & $74 \pm 2^{*}$ & $14 \pm 1$ & $7 \pm 1$ & $252 \pm 15^{*}$ & $139 \pm 11$ \\
40 min post-injection & & & & &
\end{tabular}

$\mathrm{n}=9$ in each group.

Results are mean \pm S.E.M.

${ }^{*} \mathrm{p}<0.05$ when compared to pre-injection group.

appropriate. The data are presented as a mean value \pm standard error of the mean. A value of $p<0.05$ is considered to be significant.

\section{Results}

In both groups, PAP and PCWP were initially similar and remained unchanged throughout the study (Table I). Dogs receiving bupivacaine and bupivacaine with epinephrine demonstrated a significant decrease in MABP at 20 and 40 minutes following subarachnoid injection. MABP tended to be slightly lower in dogs receiving bupivacaine with epinephrine. Cardiac output $(\mathrm{CO})$ in the two groups were initially similar. Following subarachnoid bupivacaine, a significant decrease in $\mathrm{CO}$ occurred ( 25 and 28 per cent respectively), at 20 and 40 minutes post-injection. In dogs receiving subarachnoid bupivacaine with epinephrine, a significant increase in $\mathrm{CO}$ was observed ( 33 and 25 per cent respectively), at 20 and 40 minutes following subarachnoid injection. Heart rate decreased signifcantly ( 34 and 32 per cent respectively), at 20 and 40 minutes following subarachnoid bupivacaine. Dogs receiving subarachnoid bupivacaine with epinephrine did not demonstrate a significant change in HR.

$\mathrm{PaO}_{2}, \mathrm{PaCO}_{2}, \mathrm{pH}$ and temperature were similar in the two groups during the study (Table II).

Pre-injection spinal cord and spinal dural blood flow measurements were similar in any given region in the two groups.

Animals receiving subarachnoid bupivacaine demonstrated a significant decrease in blood flow to all regions of the spinal cord (Table III). The decreases in blood flow to the cervical, thoracic and lumbosacral spinal cord regions were 38,47 and 26

TABLE II Arterial blood gases, $\mathrm{pH}$ and temperature prior to and following intrathecal injection

\begin{tabular}{lllll}
\hline Groups & $\begin{array}{l}\mathrm{PaO}_{2} \\
(\mathrm{mmHg})\end{array}$ & $\begin{array}{l}\mathrm{PaCO}_{2} \\
(\mathrm{mmHg})\end{array}$ & $p H$ & $\begin{array}{l}\text { Temperature } \\
\left({ }^{\circ} \mathrm{C}\right)\end{array}$ \\
\hline $\begin{array}{l}\text { Bupivacaine } \\
\text { Pre-injection }\end{array}$ & $486 \pm 18$ & $37 \pm 1$ & $7.38 \pm 0.02$ & $38.2 \pm 0.1$ \\
20 min post-injection & $474 \pm 19$ & $38 \pm 1$ & $7.37 \pm 0.02$ & $38.1 \pm 0.2$ \\
40 min post-injection & $479 \pm 12$ & $38 \pm 1$ & $7.35 \pm 0.02$ & $38.2 \pm 0.2$ \\
& & & & \\
Bupivacaine with epinephrine & & & & \\
Pre-injection & $423 \pm 34$ & $37 \pm 1$ & $7.39 \pm 0.02$ & $38.0 \pm 0.1$ \\
20 min post-injection & $471 \pm 14$ & $39 \pm 1$ & $7.36 \pm 0.01$ & $38.0 \pm 0.1$ \\
40 min post-injection & $479 \pm 16$ & $38 \pm 1$ & $7.36 \pm 0.01$ & $38.0 \pm 0.1$ \\
\hline
\end{tabular}

$\mathrm{n}=9$ in each group.

Results are mean \pm S.E.M.

No significant differences. 
TABLE III Spinal cord blood flow prior to and following intrathecal injection

\begin{tabular}{|c|c|c|c|}
\hline \multirow[b]{2}{*}{ Groups } & \multicolumn{3}{|c|}{ Regional flow (m/l100 gm/min) } \\
\hline & $\begin{array}{l}\text { Cervical } \\
\text { cord }\end{array}$ & $\begin{array}{l}\text { Thoracic } \\
\text { cord }\end{array}$ & $\begin{array}{l}\text { Lumbo-sacral } \\
\text { cord }\end{array}$ \\
\hline \multicolumn{4}{|l|}{ Bupivacaine } \\
\hline Pre-injection & $24 \pm 2$ & $19 \pm 1$ & $31 \pm 3$ \\
\hline 20 min post-injection & $15 \pm 1^{*}$ & $10 \pm 1^{*}$ & $23 \pm 2^{*}$ \\
\hline $40 \mathrm{~min}$ post-injection & $15 \pm 2 *$ & $11 \pm 1^{*}$ & $22 \pm 2 *$ \\
\hline \multicolumn{4}{|c|}{ Bupivacaine with epinephrine } \\
\hline Pre-injection & $25 \pm 1$ & $24 \pm 2$ & $35 \pm 2$ \\
\hline 20 min post-injection & $27 \pm 3$ & $16=2 *$ & $20=2^{*}$ \\
\hline $40 \mathrm{~min}$ post-injection & $25 \pm 3$ & $16 \pm 2^{*}$ & $21 \pm 3^{*}$ \\
\hline
\end{tabular}

$\mathbf{n}=9$ in each group.

Results are mean \pm S.E.M.

${ }^{*} p<0.05$ when compared to pre-injection group.

per cent respectively at 20 minutes and 38,42 and 29 per cent respectively at 40 minutes post-injection.

Animals receiving subarachnoid bupivacaine with epinephrine demonstrated a significant decrease in thoracic and lumbosacral spinal cord blood flow (SCBF). The decreases in thoracic and lumbosacral SCBF were 33 and 43 per cent respectively at $20 \mathrm{~min}$ post-injection and 33 and 40 per cent respectively at $40 \mathrm{~min}$. Cervical SCBF remained similar to pre-injection values at both 20 and 40 minutes.

Cervical spinal dural blood flow remained unchanged in both groups following subarachnoid injection (Table IV). A similar significant decrease in thoracic dural blood flow was observed in both groups. Lumbosacral dural blood flow significantly decreased at 20 and 40 minutes following subarachnoid bupivacaine with epinephrine while dogs receiving subarachnoid bupivacaine demonstrated a significant decrease only at 40 minutes postinjection.

\section{Discussion}

The arterial blood supply to the spinal cord of most mammalian species is similar. The afferent vascular supply is composed of one anterior and two posterior arteries which are supplied by a variable number

TABLE IV Spinal dural blood fow prior to and following intrathecal injection

\begin{tabular}{|c|c|c|c|}
\hline \multirow[b]{2}{*}{ Groups } & \multicolumn{3}{|c|}{ Regional flow $(\mathrm{mll} / 100 \mathrm{gm} / \mathrm{min})$} \\
\hline & $\begin{array}{l}\text { Cervical } \\
\text { cord }\end{array}$ & $\begin{array}{l}\text { Thoracic } \\
\text { cord }\end{array}$ & $\begin{array}{l}\text { Lumbo-sacral } \\
\text { cord }\end{array}$ \\
\hline \multicolumn{4}{|l|}{ Bupivacaine } \\
\hline Pre-injection & $5.5 \pm 1.0$ & $5.0 \pm 0.6$ & $6.2 \pm 1.0$ \\
\hline 20 min post-injection & $5.3 \pm 1.2$ & $3.5 \pm 0.5^{*}$ & $4.5 \pm 0.8$ \\
\hline $40 \mathrm{~min}$ post-injection & $5.6 \pm 1.3$ & $2.8 \pm 0.4^{*}$ & $3.2 \pm 0.6^{*}$ \\
\hline \multicolumn{4}{|c|}{ Bupivacaine with epinephrine } \\
\hline Pre-injection & $5.7 \pm 1.3$ & $4.6 \pm 0.6$ & $5.7 \pm 0.6$ \\
\hline $20 \mathrm{~min}$ post-injection & $3.8=0.7$ & $2.8 \pm 0.4^{*}$ & $1.5 \pm 0.3^{*}$ \\
\hline $40 \mathrm{~min}$ post-injection & $5.4 \pm 2.2$ & $2.3 \pm 0.2^{*}$ & $1.8 \pm 0.3^{*}$ \\
\hline
\end{tabular}


of radicular arteries. ${ }^{9,10}$ Studies of the vascular anatomy of the canine spinal cord suggest that it is comparable to that of humans. ${ }^{11-14}$

The response of the canine spinal cord circulation to subarachnoid bupivacaine with and without epinephrine was determined under conditions of stable $\mathrm{PaO}_{2}, \mathrm{PaCO}_{2}$ and temperature.

The induction of spinal anaesthesia produced significant decreases in MABP in both treatment groups, the MABP tending to be slightly lower in dogs receiving bupivacaine with epinephrine. In all dogs studied, the mean arterial blood pressure remained above $60 \mathrm{mmHg}$, i.e. the lower autoregulatory limit in pentobarbitone anaesthetized dogs. 15

The decrease in CO (25 and 28 per cent respectively at 20 and $40 \mathrm{~min}$ ) following subarachnoid bupivacaine correlates well with the decrease in HR (33 and 32 per cent respectively at 20 and $40 \mathrm{~min}$ ). In view of the stable PCWP's, this suggests that the decreased $\mathrm{CO}$ was secondary to cardiac sympathetic dennervation from high spinal anaesthesia rather than a direct depressant effect of systemically absorbed bupivacaine. In dogs receiving bupivacaine with epinephrine, the increase in $\mathrm{CO}$ was probably secondary to increased contractility, as PCWP's and HR were not increased.

Subarachnoid 0.9 per cent saline $(5 \mathrm{ml})$ does not significantly alter spinal cord blood flow at 10,20 and 40 minutes following injection. ${ }^{6,16}$ Following subarachnoid bupivacaine SCBF to the cervical, thoracic, and lumbosacral regions decreased. The reason for the decrease is difficult to explain. As noted previously, cardiac index decreased 25 per cent at $20 \mathrm{~min}$ following subarachnoid injection. The decreases in blood flow were 38,47 and 26 per cent in the cervical, thoracic and lumbosacral spinal cord regions respectively at 20 minutes. The decrease in cardiac output is therefore insufficient to fully explain the decreases in cervical and thoracic SCBF. In order to explain the decreases in blood flow, one would have to postulate in addition a decrease in vascular resistance in peripheral vascular beds which is greater than that seen in the spinal cord vascular bed. If this occurred concurrently with a loss of spinal circulatory autoregulation, a preferential steal could be postulated. However, if this is assumed, then it becomes difficult to explain the effects of bupivacaine with epinephrine on the spinal cord circulation. In this group of dogs, a similar decrease in thoracic spinal cord blood flow occurred at $20 \mathrm{~min}$ as seen in the bupivacaine dogs, despite a 33 per cent increase in CO. Systemic absorption of epinephrine produced mainly a beta adrenergic effect as evidenced by the slightly greater decrease in MABP and increase in cardiac index. Although one could postulate a further decrease in peripheral vascular resistance and increased shunting away from the spinal cord, this would be inconsistent with our findings of normal cervical spinal cord blood flow in this group. Since it was previously demonstrated that epinephrine $(200 \mu \mathrm{g})$ intrathecally did not effect SCBF, ${ }^{16}$ the decrease in SCBF in all probability is due to the effects of bupivacaine on the regional circulation.

Our findings with bupivacaine are in contrast to those previously observed with subarachnoid tetracaine $(20 \mathrm{mg}$ ). Tetracaine produced a 123 and 162 per cent increase in lumbosacral SCBF at 20 and 40 minutes respectively after administration. Spinal cord blood flow to the cervical and thoracic regions was not effected following subarachnoid tetracaine. The addition of epinephrine prevented the lumbosacral hyperemia response seen with tetracaine.

The specific reason for the differing effects of the two agents following equipotent subarachnoid doses is unclear. The decrease in MABP following subarachnoid tetracaine was 24 and 21 per cent at 20 and 40 minutes respectively, while the decrease with bupivacaine was 29 and 33 per cent at 20 and 40 minutes respectively. The slightly greater decrease in MABP with bupivacaine should not in itself have produced the marked differences in SCBF since SCBF has been shown to be maintained to a lower MABP of $60 \mathrm{mmHg}$ in dogs. This would have necessitated a much greater ( $>50$ per cent) decrease in MABP from control values.

Bupivacaine, which is approximately threefold less lipid soluble than tetracaine, ${ }^{17}$ may diffuse into the spinal cord at a slower rate. However, if this was the only mechanism, one would expect vasodilation at some time after subarachnoid injection. It is possible that if flow were measured at $60-90$ minutes post-administration lumbosacral vasodilation may be evident. This concept is supported by the fact that $t_{\max }$ (peak concentration times) in human venous plasma samples following subarachnoid isobaric bupivacaine $(0.5$ per cent solution, $15 \mathrm{mg}$ dose) is reported as $86 \pm 24 \mathrm{~min} .{ }^{18}$ If one believes that peak venous plasma levels coincide 
with peak spinal cord tissue levels and peak uptake, then a longer observation period may be indicated. However, if one looks at our SCBF data following subarachnoid bupivacaine the SCBF values are very similar at 20 and $40 \mathrm{~min}$. This suggests a relatively steady state in regard to the vascular response and that a longer observation period may not disclose vasodilation.

The level of neural blockade in dogs in the present study was not determined. The spinal cord blood flow changes suggest that some degree of blockade at the cervical level was achieved. The high level of neural blockade makes comparisons of blood flow changes between blocked lumbar and unblocked cervical spinal cord regions not possible. Future studies with subarachnoid bupivacaine should employ a lower total dose to allow comparisons of blood flow changes between anaesthetized versus non-anaesthetized spinal cord regions.

In conclusion, we have demonstrated that subarachnoid $0.4 \%$ per cent bupivacaine $(20 \mathrm{mg}$ ) produces a generalized decrease in spinal cord blood. The addition of $1 / 25,000$ epinephrine $(200 \mu \mathrm{g})$ to bupivacaine did not significantly alter the decrease in thoracic or lumbosacral spinal cord blood flow, but maintained blood flow to the cervical region of the spinal cord. Our findings are consistent with the clinical observations that adding epinephrine to bupivacaine spinal anaesthesia will not prolong the duration of anaesthesia.

In view of the established clinical safety of subarachnoid bupivacaine no added recommendations concerning bupivacaine can be made at the present time. Epinephrine should probably be avoided as it has no useful clinical effect following subarachnoid injection with bupivacaine. Further studies related to the pharmacokinetics, local metabolic effects and direct vascular effects following subarachnoid and epidural injections of local anaesthetics are required.

\section{References}

1 Van Kleef JW, Burm AGL. Effects of adrenaline during epidural and spinal anaesthesia. In Current Concepts in Regional Anaesthesia. Edited by Van Kleef JW, Burm AGL, Spierdijk J. M. Nijhoff Publishing Co 1984; 174-85.

2 Chambers WA, Littlewood $D G$, Scott $D B$. Spinal anesthesia with hyperbaric bupivacuine: effect of added vasoconstrictors. Anesth Analg 1982; 61: 49-52.

3 Feldman HS, Covino BG. Effect of vasoconstrictor agents on prolonging the duration of spinal anaesthesia in the dog. Abstract. Anesthesiology 1983; 59: A211.

4 Armstrong IR, Littlewood DG. Chambers WA. Spinal anaesthesia with tetracaine - effect of added vasoconstrictors. Anesth Analg 1983; 62: 793-5.

5 Concepcion $M$, Maddi R, Francis D, Rocco $A G$, Murray $E$, Covino $B G$. Vasoconstrictors in spinal anesthesia with tetracaine - a comparison of epinephrine and phenylephrine. Anesth Analg 1984; 63: $134-8$.

6 Kozody R, Palahniuk RJ, Cumming MO. Spinal cord blood flow following subarachnoid tetracaine. Can Anaesth Soc J 1985; 32: 23-9.

7 Heymann MA, Payne BD, Hoffman JIE, Rudolph $A M$. Blood flow measurements with radionuclide labelled particles. Progr Cardiovasc Dis 1977; 20: $55-79$.

8 Hales JRS. Radioactive microsphere techniques for studies of the circulation. Clin Exper Pharmacol Physiol 1974; Suppl 1, 31-46.

9 de la Torre JC. Spinal cord injury - review of basic and applied research. Spine 1981; 6: 315-35.

10 Craigie EH. Vascular supply. In The Spinal Cord 3rd Edition. Edited by Austin GM. Igaku Shoin Ltd. 1983; 47-70.

11 Margolis $G$, Griffin AT, Kenan PD, Tindall $G$, Laughlin EH, Phillips RL. Circulatory dynamics of the canine spinal cord. Neurosurgery 1957; 14: 506-14.

12 Adams HD, Van Geertruyden HH. Neurological complications of Aortic Surgery. Ann Surg 1956; 144: 574-609.

13 Giuseffi $J$, Greene $L W J r$, Vetto $M$. Experiments on occlusion of the abdominal aorta in normothermic dogs. Surgery, Gynecology and Obstetrics 1957; 105: 427-34. 
14 Suh TH, Alexander L. Vascular system of the human spinal cord. Arch Neurol Psychiatr 1939; 41: 659-77.

15 Griffith IR. Spinal cord blood flow in dogs; the effect of blood pressure. J Neurol Neurosurg Psych 1973; 36: 914-20.

16 Kozody R, Palahniuk RJ, Wade JG, Cumming MO, Pucci WR. The effect of subarachnoid epinephrine and phenylephrine on spinal cord blood flow. Can Anaesth Soc J 1984; 31: 503-8.

17 Covino BG, Vassallo HG. Local anesthetics. New York, New York. Grune and Stratton Inc. Publishers 1976: 46.

18 Burm AG, Van Kleef JW, Gladines MP, Spierdijk J, Breimer $D D$. Plasma concentrations of lidocaine and bupivacaine after subarachnoid administration. Anesthesiology 1983; 59: 191-5.

\section{Résumé}

Dix-huit chiens bâtards ont été randomisés en deux groupes égaux. Les débits sanguins de la moelle épinière et de la duremère dans les régions cervicale, thoracique et lombo-sacrée ont été mesurés en utilisant la technique des microsphères radioactives. Les déterminations des flots snaguins ont été faites avant, 20 et 40 minutes après l' injection sous-arachnoïdienne lombaire de : 1) 0.4 pour cent bupivacaine $(20 \mathrm{mg})$ ou, 2) 0.4 pour cent bupivacaïne $(20 \mathrm{mg})$ avec $1 / 25,000$ épinéphrine $(200 \mu \mathrm{g})$. Les chiens ayant reçu l'injection de bupivacaine sousarachnoïdienne ont démontré une diminution significative dans le flot sanguin de la moelle épinière dans toutes les régions. Les chiens ayant reçu la bupivacaine intrathécale avec épinéphrine ont démontré une diminution significative du flot sanguin dans les régions thoracique et lombo-sacrée: cependant, le flot sanguin de la moelle épinière dans la région cervicale est demeuré inchangé. Les flots sanguins de la duremère dans les régions thoracique et lombo-sacrée ont été diminués significativement dans les deux groupes après injection sous-arachnoïdienne.

L'injection sous-arachnoïdienne de bupivacaïne 0.4 pour cent $(20 \mathrm{mg})$ et 0.4 pour cent avec épinéphrine $1 / 25,000(200 \mu \mathrm{g})$ diminue le flot sanguin dans la moelle épinière ainsi que dans la duremère chez les chiens. 